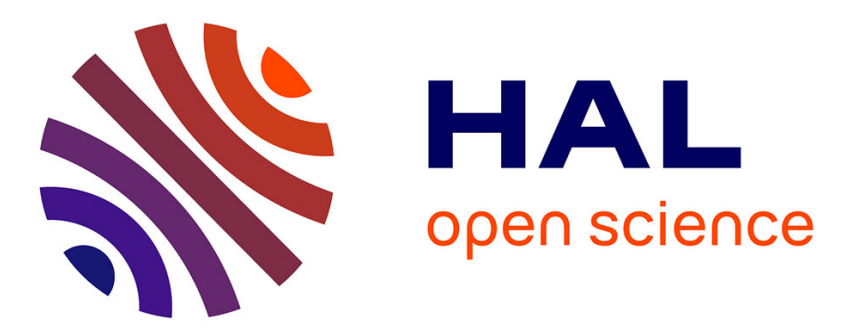

\title{
Impact of drainage on soil-forming mechanisms in a French Albeluvisol: Input of mineralogical data in mass-balance modelling
}

David Montagne, Sophie Cornu, Lydie Le Forestier, Michel Hardy, O. Josière, Laurent Caner, Isabelle Cousin

\section{To cite this version:}

David Montagne, Sophie Cornu, Lydie Le Forestier, Michel Hardy, O. Josière, et al.. Impact of drainage on soil-forming mechanisms in a French Albeluvisol: Input of mineralogical data in massbalance modelling. Geoderma, 2008, 145 (3-4), pp.426-438. 10.1016/j.geoderma.2008.02.005 . insu00286941

\section{HAL Id: insu-00286941 https://hal-insu.archives-ouvertes.fr/insu-00286941}

Submitted on 10 Jun 2008

HAL is a multi-disciplinary open access archive for the deposit and dissemination of scientific research documents, whether they are published or not. The documents may come from teaching and research institutions in France or abroad, or from public or private research centers.
L'archive ouverte pluridisciplinaire HAL, est destinée au dépôt et à la diffusion de documents scientifiques de niveau recherche, publiés ou non, émanant des établissements d'enseignement et de recherche français ou étrangers, des laboratoires publics ou privés. 
Impact of drainage on soil-forming mechanisms in a French Albeluvisol: Input of mineralogical data in mass-balance modelling

\title{
D. Montagne a, , S. Cornu ${ }^{a}$, L. Le Forestier ${ }^{b}$, M. Hardy ${ }^{a}$, O. Josière ${ }^{a}$, L. Caner ${ }^{c}$ and I. Cousin $^{\mathrm{a}}$
}

${ }^{a}$ INRA, Centre de Recherche d'Orléans, UR 0272 Unité de Science du Sol, 2163 Avenue de la Pomme de Pin, BP 20619 Ardon, F-45166 Olivet Cedex, France

${ }^{\mathrm{b}}$ ISTO, UMR 6113 CNRS/Université d'Orléans, Polytech'Orléans, 8 rue Léonard de Vinci, F45072 Orléans Cedex, France

'Université de Poitiers, UMR 6532 CNRS, Laboratoire HydrASA, 40 avenue du recteur Pineau, F-86022 Poitiers Cedex, France

\begin{abstract}
Research on soil pedogenesis has mainly focused on the long-term soil formation and has most often neglected recent soil evolutions in response to human practices. Such recent soil evolutions are however of considerable interest to study the timing of soil forming processes in response to changes in environmental conditions. In this paper, we model the Albeluvisol evolution in response to agricultural drainage. This was considered as a model case to study the velocity of mineralogical changes in soil as a result of eluviation and redox processes. We used a space-for-time substitution approach in combination with mass balance modelling based on mineralogical data in order to identify and characterise the mineralogical transformations responsible for the recent soil evolution in response to subsurface drainage. This approach allowed demonstrating that the main effects of subsurface drainage are (i) increasing precipitation of Mn oxides and Mn-rich ferrihydrite with decreasing distance to the drain as a result of the change in redox conditions and (ii) increasing loss of clay-sized oxides and smectites due to the enhanced eluviation in the vicinity of the drain. Both processes induce significant matter fluxes in comparison with those that occurred over the long-term soil formation. Nowadays, the precipitation of Mn oxides and Mn-rich ferrihydrite seems to still be active in the studied soil. On the opposite, the eluviation process appears less active than immediately after the drainage network installation, if not totally inactive. It thus demonstrates that some soil processes may have significant impact on the soil mineralogical composition even if they are only active over very short periods of time after a change in environmental conditions.
\end{abstract}

Keywords: Pedogenesis modelling; Agricultural practices; Artificial drainage; Eluviation; Redox processes; Albeluvisol

\section{Introduction}

Human activities were early recognized as external factors affecting soil evolution ([Jenny, 1941], [Bidwell and Hole, 1965] and [Yaalon and Yaron, 1966]), but their consequences on soil changes are still poorly understood and very rarely quantified (Richter and Markewitz, 2001). These human-induced soil evolution can however be of large extent and are mostly irreversible as demonstrated by the few existing works on that subject ([Quideau and Bockeim, 1996], [Langhor, 2001], [Jussy et al., 2002], [Lima et al., 2002], [Kleber et al., 
2003] and [Gerlach et al., 2004]). Indeed changes in soil chemical, physical and biological properties have been observed within a few decades ([Cattle et al., 1994], [Boag et al., 1997], [Goulding and Blake, 1998], [Richard et al., 2001], [Caravaca et al., 2002] and [Chantigny, 2003]). Understanding their consequences on soil evolution is thus of great importance in terms of soil sustainability.

In addition human-induced soil evolutions can be easily dated thanks to historical or even prehistorical records, while soil long-term formation are more difficult to rate. These humaninduced evolutions are thus of great interest to study the rates of soil-forming processes. Indeed, the rates of soil processes remain poorly known, although their knowledge is a keypoint to model soil pedogenesis. Soil formation is classically considered as a slow process. Wilkinson et al. (2005) gives $10^{4}$ to $10^{5}$ years as an average of soil ages. Some study demonstrated rapid soil evolutions in various pedological contexts. As an example, Burt and Alexander (1996), studying a chronosequence of podzolic soils, reported that the formation of the organic horizon was completed within 38 years only while the E/Bhs layering was macromorphologically identified within 70 years. Other even faster mineralogical changes were observed in soils as significant feldspar dissolution within 3 years only in podzols and cambisols (Augusto et al., 2000) or permanent kaolinite dissolution/precipitation with significant evolutions in time scales as short as 6 months in tropical soils ([Cornu et al., 1995] and [Lucas et al., 1996]).

Montagne (2006) quantified clear soil evolution due to 16 years of subsurface drainage in a French Albeluvisol: eluviation was enhanced and redox processes modified. Subsurface drainage appears thus as a model case for studying the velocity of changes in the soil mineralogical composition as a result of two of the major soil processes, namely eluviation and redox ones. In this paper, changes in the mineralogical composition after 16 years of subsurface drainage were modelled using a space-for-time substitution approach and an adapted mass-balance modelling. Indeed this modelling was first developed for computing the geochemical fluxes resulting from soil formation (Brimhall et al., 1991). We used it here in introducing mineralogical data.

\section{Materials and methods}

\subsection{Studied site and soil}

The studied site lies on the crest of the Yonne plateau, France (Fig. 1), where Albeluvisols developed in Quaternary loam of aeolian origin deposited over an Eocene clay layer (Baize and Voilliot, 1988). The Quaternary aeolian deposit that constitutes the parent material of the studied soil is never calcareous and generally contains from 70 to $90 \%$ of silt-size particles and from 5 to $20 \%$ of clay-size particles (Pomerol, 1988). It rarely exceeds $1 \mathrm{~m}$ of thickness and is generally entirely weathered. This deposit was formed during dry and cold episodes of the Quaternary period. As a consequence the studied soil is supposed to be at least thousandyear old.

Present climatic conditions for the studied site are $10{ }^{\circ} \mathrm{C}$ mean annual temperature and ca. $800 \mathrm{~mm}$ mean annual precipitation (Baize and Voilliot, 1988). Precipitations are regularly distributed throughout the year with a slight increase in December and January. In that period of the year a perched water table is observed within the upper horizons of the soil and the drain starts to outflow. The studied soils was cultivated since at least 200 years (Cadastre, 1828) and shows the following horizonation: 
- From 0 to 25 (30) cm: a silty, brown to grey ploughed surface horizon with numerous black concretions.

- From 25 (30) to $35(40) \mathrm{cm}$ : a silty E-horizon, greyer than the overlying horizon (10YR6/4).

- From 35 (40) to 55 (60) cm: a horizon constituted by a complex mixture of several soil volumes of distinctive colours. The most abundant ones are silty and of a white-grey (10YR8/2 to 10 YR7/1) to pale-brown (10YR7/4) colour. The less abundant ones are around $10-\mathrm{cm}$ in size, clayey and of an ochre colour (10YR5/6 to 10YR5/8). Black concretions and impregnations occur in the core of these last volumes. For convenience, we call this horizon hereafter the E\&Bt-horizon.

- From 55 (60) to 90 (105) cm: the degraded Bt-horizon shows a juxtaposition of the previously described soil volumes, the most abundant being the ochre ones. The white-grey and the pale-brown ones differ slightly in colour from the upper ones and are present as tongues with small amounts of a clay-rich and salmon-brown (10YR6/2) volumes. Black impregnations are less abundant than in the overlying horizon.

In the studied plot, a subsurface drainage network was installed, in 1988 (16 years before sampling), by subsoiling, perpendicular to the main slope, at 1-m depth and spaced $15 \mathrm{~m}$ apart. We dug a 4-m-long trench perpendicularly to one of the drains, providing the following macroscopic observations (Fig. 2):

(i) The thickness of the different horizons does not vary by more than $5 \mathrm{~cm}$, which was not considered as significant;

(ii) Within a distance of about $0.5 \mathrm{~m}$ on both sides of the drain in the E\&Bt-horizon, the soil is disturbed by subsoiling operations during the drain installation as shown by a clear

disorganization in the arrangement of the ochre and light-coloured soil volumes. This was not the case anymore beyond $0.5 \mathrm{~m}$;

(iii) As the distance to the drain decreases from 2 to $0.5 \mathrm{~m}$, the relative abundance of the white-grey, pale-brown and black soil volumes increased both in the E\&Bt- and in the degraded Bt-horizons. On the contrary, that of the clayey ochre soil volume decreased;

(iv) Beyond $2 \mathrm{~m}$ from the drain, the amounts of the different soil volumes do not change significantly.

\subsection{Soil sampling strategy}

On the basis of the previous morphological observations, we sampled, a soil sequence comprising portions affected and unaffected by soil drainage (Table 1). The soil was sampled at three places of increasing distance to a drain, namely at 60,210 , and $400 \mathrm{~cm}$. At each of these "positions", a pair of two undisturbed soil monoliths of about $27 \times 15 \times 12 \mathrm{~cm}$ was sampled both on the whole E\&Bt-horizon and on the upper $10 \mathrm{~cm}$ of the degraded Bt-horizon, hereafter called "Bt-horizon" for simplicity. Preliminary analysis indeed demonstrates that the particle-size distribution and the Fe and Mn total concentrations changed as a function of the distance to the drain only in these two horizons (Table 1). One monolith was used for quantification of the relative abundance of the different soil volumes and the other for determination of their mineralogical composition. 


\subsection{Quantification of soil volumes by image analysis}

We used image analysis for quantifying the relative abundance of the different soil volumes: four in the E\&Bt-horizon (white-grey, pale-brown, ochre and black) and five in the Bthorizon (white-grey, pale-brown, salmon-brown, ochre and black). This analysis was based on a supervised classification method using the ERDAS IMAGINE ${ }^{\circledR}$ commercial software package (Leica Geosystems GIS \& Mapping LLC, 2003) as described in Montagne et al. (2007). The quantifications are given in Table 2.

\subsection{Characterization of soil volumes}

Sequential extraction was performed to quantify the different forms of $\mathrm{Fe}$ and $\mathrm{Mn}$ as a function of the soil volume and of the distance to the drain, in order to assess the impact of agricultural drainage on redox processes. X-ray diffraction and thermal analysis are mostly used for characterizing well-crystallized minerals, notably clay minerals. They were thus used to trace the impact of agricultural drainage on the eluviation process.

\subsubsection{Sequential extraction}

Sequential extraction was performed on the different soil volumes of the two horizons and for the different distances to the drain, with the exception of the pale-brown soil volumes in the Bt-horizon as they could not be sampled due to their relatively small abundance and their scattered spatial distribution. An extraction protocol based on that developed by Benitez and Dubois (1999) and Cornu et al. (2006) was used. However, in order to differentiate Mn oxides, which are very sensitive to variations in the redox conditions, from the various forms of Fe oxy-hydroxides, we added a step based on the work by Hall et al. (1996a).

The protocol comprised the following six steps:

- Step 1: extraction by $1 \mathrm{M}$ sodium acetate and acetic acid at $\mathrm{pH} 5.5$ for $6 \mathrm{~h}$ (solid/liquid ratio $=1 / 20$ ) for "exchangeable, adsorbed and carbonate-occluded Fe and Mn";

- Step 2: extraction by $0.25 \mathrm{M}$ hydroxylamine hydrochloride in hydrochloric acid for $30 \mathrm{~min}$ ( solid/liquid ratio $=1 / 20$ ) for "Fe and Mn occluded in Mn oxides";

- Step 3: extraction by $0.1 \mathrm{M}$ sodium pyrophosphate at $\mathrm{pH} 10$ for $1.5 \mathrm{~h}$ (solid/liquid ratio $=1 / 10$ ) for "Fe and Mn occluded in organic matter";

- Step 4: extraction by $0.25 \mathrm{M}$ hydroxylamine hydrochloride at $60{ }^{\circ} \mathrm{C}$ for $2 \mathrm{~h}$ (solid/liquid ratio $=1 / 20$ ) for "Fe and Mn occluded in poorly crystalline oxides";

- Step 5: extraction by $1 \mathrm{M}$ hydroxylamine hydrochloride in acetic acid 25\% (solid/liquid ratio $=1 / 30$ ) at $90{ }^{\circ} \mathrm{C}$ for $3 \mathrm{~h}$ for "Fe and Mn occluded in strongly crystalline oxides";

- Step 6: total dissolution of solid residues in $\mathrm{HF}+\mathrm{HClO}_{4}+\mathrm{HCl}$ (Ciesielsky et al., 1997).

The black volumes were subjected to a simplified protocol, composed of steps 2, 4, 5 and 6, exclusively aiming at the quantification of the various types of oxides. Steps 1, 2, 4 and 5 were repeated twice. 
The samples were rinsed with deionised water after each extraction step. The rinse consisted of $20 \mathrm{~mL}$ of water with a contact time of $1 \mathrm{~h}$. All the extraction- and rinse-solutions were filtered through a $0.2 \mu \mathrm{m}$ filter, acidified with ultra-pure $\mathrm{HNO}_{3}$, and analysed for $\mathrm{Fe}$ and $\mathrm{Mn}$ by atomic absorption spectrometry. Extractions were done in triplicate using $1 \mathrm{~g}$ of soil sample ground to $50 \mu \mathrm{m}$. Most reactants used were either Merck suprapur or Prolabo Normatom ultrapur grade. Pyrophosphate and hydroxylamine were a Prolabo pro-analysis and a Merck analytical-grade reagent respectively, as no higher grade exists for these two products.

The blanks were analysed and their concentrations were subtracted from those measured in the different extraction solutions. Total concentrations were calculated by adding the different quantities extracted during each step, and compared to the total Fe and Mn concentrations measured for the different soil volumes (Ciesielsky et al., 1997; Table 2). The analyses made on the three replicates were averaged and their variation coefficients were calculated. In the following only the average values and the variation coefficients are presented.

\subsection{2. $X$-ray diffraction analyses}

XRD analyses were made on the $<2 \mu \mathrm{m}$ fraction - called lutum (Stichting voor Bodemkaartering, 1965) - of white-grey, pale-brown and ochre volumes of the E\&Bt-horizon at positions 60 and 400. Indeed, at these positions the strongest variations in lutum concentration were measured with the Robinson pipette method (Table 2). The lutum was separated from the total soil through sedimentation according to Stokes law and then analysed on oriented slides according to the method described by Robert and Tessier (1974). The X-ray

diffraction patterns were obtained on a Philips PW-1730 diffractometer with a CuK source and a rear monochromator running at $45 \mathrm{kV}$ and $30 \mathrm{~mA}$. After treatment with ethylene glycol, the Mg-saturated slides were analysed for angles between 3 and $47^{\circ} 2 \theta$ with an angular step of $0.02^{\circ}$ and a counting time of $20 \mathrm{~s}$ per step. The X-ray diffraction patterns obtained after treatment with ethylene glycol were decomposed into elementary peaks by the method proposed by Lanson (1997) using DECOMPXR software (Lanson, 1993).

Finally, the quartz concentration in the lutum fraction $(0-2 \mu \mathrm{m})$ was measured using $\mathrm{ZnO}$ as internal standard as described in Hardy (1992).

\subsubsection{Thermal analyses}

We carried out a thermogravimetric analysis on a Setaram Setsys Evolution TGA-DSC thermal analyser, with a heating and cooling velocity of $20^{\circ} \mathrm{C} \min ^{-1}$ between 20 and $1200{ }^{\circ} \mathrm{C}$ and a $30 \mathrm{~min}$ stage at $1200^{\circ} \mathrm{C}$. This analysis was performed on $60 \mathrm{mg}$ for the different soil volumes of the E\&Bt-horizon at the three positions 60,210 , and 400 . The clay minerals in these samples were quantified from the mass losses between 400 and $600{ }^{\circ} \mathrm{C}$ (Karathanasis and Harris, 1994).

\subsubsection{Mass-balance calculations}

Present stocks were calculated for each element $j$, in each of the soil volumes, according to the following equation: 
In this equation, $S_{j}$ is the present stock of $j$ in $\mathrm{g}, \rho$ is the bulk density in $\mathrm{g} \mathrm{cm}^{-3}, C_{j}$ is the concentration of $j$ in weight percent and $V$ is the volume of the considered soil volume in $\mathrm{cm}^{3}$. The bulk density of the different soil volumes was determined by the kerosene method on 15 replicates of undisturbed clods (Monnier et al., 1973). Volume $V$ is obtained for each soil volume from quantification by image analysis as following: for a unit area of $1 \mathrm{~cm}^{2}$, the volume $\left(\mathrm{cm}^{3}\right)$ occupied by a soil volume whose relative abundance $A$ (in \%) is equal to

$$
\text { Th } \times \frac{A}{100} \text {, }
$$

where $\mathrm{Th}(\mathrm{cm})$ is the thickness of the considered horizon.

The overall mass flux for any soil volume $m_{j, \text { flux }}$ in $\mathrm{g} \mathrm{cm}^{-2}$ was then calculated for each element $j$ using Eq. (3) proposed by Brimhall et al. (1991) and modified by Egli and Fitze (2000):

$$
m_{j, \text { flux }}=\frac{1}{100} \times \frac{\rho_{\text {ref }} \times C_{j, \text { ref }} \times \mathrm{Th} \times \tau_{j, \mathrm{w}}}{\varepsilon_{i, \mathrm{w}}+1}
$$

in which the subscripts ref and w refer, respectively, to the soil volume taken as a reference i.e. the parent material in Brimhall's approach - and to the weathered product; $\varepsilon_{i, \mathrm{w}}$ and $\tau_{j, \mathrm{w}}$ are respectively the strain and the open-system mass-transport functions. These functions were defined by Brimhall et al. (1991) to represent, for $\varepsilon_{i, \mathrm{w}}$, the soil-volume change over time using an immobile element $i$ and, for $\tau_{j, \mathrm{w}}$, the mass fraction of element $j$ gained or lost from the weathered product with respect to the mass originally present in the parent material. They were calculated according to the following equations:

$$
\begin{aligned}
\varepsilon_{i, \mathrm{w}} & =\frac{\rho_{\text {ref }} C_{i, \mathrm{ref}}}{\rho_{\mathrm{w}} C_{i, \mathrm{w}}}-1 \\
\tau_{j, \mathrm{w}} & =\frac{\rho_{\mathrm{w}} C_{j, \mathrm{w}}}{\rho_{\text {ref }} C_{j, \mathrm{ref}}}\left(\varepsilon_{i, \mathrm{w}}+1\right)-1 .
\end{aligned}
$$

To compute these functions, quartz was selected as the immobile element (Montagne, 2006).

By comparison with classic studies using mass-balance models, the present one shows two specific points. First, we chose the ochre soil volumes as reference material for computing 
mass-balance fluxes. Indeed these volumes are residual and inherited from the initial Bthorizon before "morphological degradation". Morphological degradation is characteristic of Albeluvisol. It consists in the formation, over time, of a complex juxtaposition of a bleached eluvial E-horizon with residual soil volumes of the initial and non-degraded illuvial Bthorizon ([Jamagne, 1978], [Pedro et al., 1978] and [Driessen et al., 2001]). This phenomenon is superimposed on the non-degraded illuvial horizon form by eluviation-illuviation in Luvisol. The use as reference material of ochre soil volumes allows thus quantifying matter fluxes related to the "morphological degradation" processes independently from the previous ones. Secondly, the calculations were not done on total chemical concentrations but on the results of sequential extraction that more or less corresponded to specific and known minerals. Such approach was used for example by Jersak et al. (1997 to improve the understanding of the long-term fate of trace metal in podzols. It thus allowed computing fluxes of operationally defined chemical fractions tentatively assigned to well-defined minerals instead of chemicalelement fluxes. Finally, errors on calculations were estimated according to Montagne (2006).

\section{Results and discussion}

\subsection{Impact of redox processes on the different forms of Fe and Mn}

\subsubsection{Quality of the sequential extractions}

For each sequential-extraction step, the coefficients of variations for the $\mathrm{Fe}$ - and $\mathrm{Mn}$ concentrations are mostly below $5 \%$, rarely exceed $10 \%$ and reach $15 \%$ in only two cases. Those of the total concentrations are always below 5\%. This low variability between replicates allows interpreting, with a high level of confidence, the observed variations of the quantities of $\mathrm{Fe}$ and $\mathrm{Mn}$ extracted during the different extractions in terms of changes in iron and manganese forms. Finally, a comparison of the calculated and measured total Fe and $\mathrm{Mn}$ concentrations shows that 10 to $30 \%$ of the iron and manganese initially contained in the different soil volumes were lost likely as colloids after the pyrophosphate extraction (Cornu et al., 2006). For the black volumes no pyrophosphate extraction was performed. In this case, the difference between the measured and calculated total concentrations was lower than $10 \%$ and thus of the same order of magnitude than the classically admitted analytical error for sequential extraction (Tessier et al., 1979). This result reinforces our previous interpretation of the colloid losses.

\subsubsection{Identification of mineral phases quantified by the different sequential- extraction steps}

The first step mainly aims at extracting the exchangeable forms, adsorbed by and linked to carbonates (Han and Banin, 1995). However, XRD analyses on total-soil samples show that the different soil volumes of the E\&Bt-horizon do not contain carbonates. The iron and manganese extracted during this step thus occur mainly as exchangeable and adsorbed forms. The very small quantities of Fe and Mn extracted during this step are coherent with the small quantities of solid phases with high exchange and adsorption capacity in the studied samples ( $<0.3 \%$ of organic matter, from 20 to $30 \%$ of lutum according to the soil volume considered, and $<5 \%$ of total iron).

In the black soil volumes of both horizons, the quantities of Mn cold-extracted with hydroxylamine (step 2) represent most of the Mn contained in these volumes (Fig. 3). On the contrary, only very small quantities of Fe, never exceeding a few percent of total iron, are 
extracted with this same extraction (Fig. 4). This difference between the quantities of Mn and Fe extracted during this step is also observed in the other volumes. This extraction thus appears selective for Mn oxides, as was already shown by Liu et al. (2002) These oxides could not be identified by XRD, probably because of too low concentrations and/or a weak crystallinity (McKenzie, 1977). We suggest that these oxides are lithiophorite and/or birnessite ([McKenzie, 1977], [Liu et al., 2002] and [Manceau et al., 2003]).

Step 3 covers the extraction of elements associated to organic matter (Hall et al., 1996b). Pyrophosphate, however, is a powerful deflocculant that can put into suspension colloids rich in Fe and Mn (Jeanroy and Guillet, 1981). Such a phenomenon is coherent with the clogging of filters observed during this extraction step and might be the cause, at least partially, of the observed Fe and Mn losses. This hypothesis is also coherent with the absence of Fe and $\mathrm{Mn}$ losses in the case of the black volumes, for which no extraction with pyrophosphate took place. Moreover, the organic-matter concentration is very low. Therefore, the losses as well as the Fe and Mn extracted during step 3 apparently correspond to colloidal iron oxides, probably ferrihydrite.

Steps 4 and 5 are designated for the attack of amorphous and poorly-crystallized (step 4), and well-crystallized (step 5) iron oxides (Hall et al., 1996a). The main amorphous and poorlycrystallized Fe oxide in soil is ferrihydrite ([Schwertmann and Taylor, 1977], [Hall et al., 1996a] and [Liu et al., 2002]). The quantities of iron extracted with hydroxylamine at $60^{\circ} \mathrm{C}$ can thus be considered as being mainly associated with this mineral. Hematite, goethite, lepidocrocite, maghemite and magnetite form well-crystallized iron oxides ([Schwertmann and Taylor, 1977] and [Cornell and Schwertmann, 1996]). However, in the ochre volumes of position 400, which contain the largest quantities of iron extracted with hydroxylamine at $90{ }^{\circ} \mathrm{C}$, the peak at $0.417 \mathrm{~nm}$ (Fig. 5) shows that goethite is more abundant in these volumes than in the others of position 400 and than in the different volumes of position 60 . No other crystallized iron oxy-hydroxide was detected by XRD. Therefore, the quantities of iron extracted with hydroxylamine at $90{ }^{\circ} \mathrm{C}$ are mainly attributed to the dissolution of goethite.

According to XRD analyses of total-soil samples, the solid residue is mainly composed of silicates, i.e. quartz, feldspars and different types of clay minerals. The Fe and $\mathrm{Mn}$ found in the residues are principally attributed to the different clay minerals.

In the discussion hereafter, the Fe and Mn extracted during the different steps will be named by their associated minerals. These are goethite for step 5 and clays for step 6 . For step 2, we keep the designation "Mn oxides" as this most likely covers birnessite and/or lithiophorite. The quantities of $\mathrm{Fe}$ and $\mathrm{Mn}$ lost during sequential extraction and extracted during steps 3 and 4, attributed to ferrihydrite, will be summed up hereafter.

\subsubsection{Evolution of the iron and manganese distribution}

\subsubsection{Fe and Mn distribution in the reference ochre soil volume of the Bt-horizon}

In the ochre soil volumes of the Bt-horizon (Fig. 3) and regardless of the position considered, $\mathrm{Mn}$ is mainly associated with ferrihydrite (around $50 \%$ of total $\mathrm{Mn}$ ) and with clays ( 25 to $30 \%$ of total Mn). The remainder is distributed between Mn oxy-hydroxides (slightly over $10 \%$ of total Mn except at $210 \mathrm{~cm}$ where Mn oxides show higher Mn concentrations at the expense of Mn associated with ferrihydrite), goethite ( $10 \%$ of total $\mathrm{Mn})$ and very small quantities extracted during step $1(<2 \%)$. 
Regardless of the distance to the drain, the iron contained in the ochre volumes of the Bthorizon (Fig. 4) mainly occurs as ferrihydrite (from 45 to $50 \%$ of total Fe depending upon the position considered) and goethite (35 to $40 \%$ of total iron depending upon the position considered). The iron associated with clays represents $15 \%$ of the total iron. Finally, negligible quantities are extracted during the first two extractions (together $<1 \%$ ).

As the total concentration (Table 2), the quantities of Fe and Mn extracted from the ochre volumes of the Bt-horizon during the different steps generally vary little with the distance to the drain (Fig. 3 and Fig. 4). Therefore, as a first approximation, we consider it acceptable to use the ochre volumes of the Bt-horizon as a reference. The mass flux responsible for the differentiation of the other soil volumes will thus be calculated with reference to the average concentrations measured in the ochre volumes of the Bt-horizon at the three positions 60,210 and 400 .

\subsubsection{Fe and Mn distribution as a function of the soil volume and of the distance to the drain}

Fig. 3 and Fig. 4 show that the clearest changes in the distribution of iron and manganese are seen between the different soil volumes, and that they concern all forms of $\mathrm{Fe}$ and $\mathrm{Mn}$. Changes in terms of the distance to a drain are less clear and concern only certain specific forms of $\mathrm{Fe}$ and $\mathrm{Mn}$.

In the two horizons, the quantities of Fe and Mn extracted during the different steps decrease from the ochre volumes to the white-grey ones, except for the Fe and especially $\mathrm{Mn}$ in the clays fraction that show relatively stable quantities (Fig. 3 and Fig. 4). The dissolution of clay minerals through ferrolysis is commonly evoked to explain the contrasts in texture between the ochre and the lighter-coloured volumes ([Jamagne, 1978], [Pedro et al., 1978], [Brinkman, 1979], [Stolt et al., 1994], [Hardy et al., 1999] and [Driessen et al., 2001]). However, the relative stability of the Fe and Mn quantities in the clays fraction indicates that, if the ferrolysis process is active in the studied soil, it is not the main process responsible for the differentiation of the light-coloured (white-grey and pale-brown) volumes. This result agrees with the work by Jamagne et al. (1984) and Van Ranst and De Coninck (2002). From the ochre to the white-grey soil volumes, Fe concentrations in the goethite fraction and $\mathrm{Mn}$ in the ferrihydrite fractions decreased most markedly.

Black volumes are characterized by quantities and forms of $\mathrm{Fe}$ and $\mathrm{Mn}$ that are different from those seen in the ochre volumes of the Bt-horizon. Black volumes are considerably enriched in $\mathrm{Mn}$, i.e. at least an order of magnitude more than in the ochre volumes. Moreover, at least $90 \%$ of the Mn contained in the black volumes occurs as Mn oxides, whereas these form accounted for only slightly over $10 \%$ of the total $\mathrm{Mn}$ of the ochre volumes of the Bt-horizon (Fig. 3). The quantities of iron associated with Mn oxides and as ferrihydrite in the black volumes of the E\&Bt-horizon are larger than those of the other volumes, regardless of the distance to the drain, whereas the quantities of the other forms of iron do not change greatly with reference to the ochre soil volumes. In addition, the $\mathrm{Mn} / \mathrm{Fe}$ ratio of ferrihydrite increases from ochre to black volumes by a factor 2 in both horizons (Table 3 ). No change was observed in the $\mathrm{Mn} / \mathrm{Fe}$ ratio for goethite (Table 3). These results suggest that the goethite is inherited from the soil matrix and is cemented by the precipitation of Mn oxides and a ferrihydrite richer in Mn than that initially contained in ochre volumes. The Fe and Mn that compose part of these black volumes probably derive from dissolution of the initial goethite and ferrihydrite, relatively depleted in $\mathrm{Mn}$, the abundance of which decreases from the ochre 
to the white-grey volumes. The black volumes would thus be the result of the precipitation of Mn oxides and Mn-rich ferrihydrite, after dissolution of the different initial forms of $\mathrm{Fe}$ oxides.

Mn oxide quantities are higher in the different soil volumes at the two positions 60 and 210 than at position 400, except in the black volumes. This is probably related to the progressive formation, through diffuse impregnation within the different volume types, of black volumes strongly enriched in Mn oxides whose abundance increases with decreasing distance to the drain. The formation of iron and/or manganese concretions and nodules (the black soil volumes) from diffuse impregnations (not selectively sampled in this study) was described in detail by Stolt et al. (1994).

\subsection{Impact of eluviation on the mineralogy of the different soil volumes}

\subsubsection{Characterization of the silicate phases of lutum}

Lutum is composed of quartz (peaks at 0.334 and $0.425 \mathrm{~nm}$, Fig. 5), small quantities of Kfeldspars and plagioclases (peaks at 0.319 and $0.324 \mathrm{~nm}$ ), and different types of clay minerals including kaolinite (peaks at 0.714 and $0.357 \mathrm{~nm}$ remaining after ethylene-glycol treatment, Fig. 5). The X-ray diffraction patterns of the oriented preparations solvated with ethylene glycol were decomposed for a range of angles from 4 to $10^{\circ} 2 \theta$, evidencing four other types of clay minerals (Fig. 6):

(i) Well crystallized illite, shown by the persistence of a narrow peak at $1.0 \mathrm{~nm}$ after treatment with ethylene glycol (Fig. 6), and by the presence of a peak at $0.5 \mathrm{~nm}$ (Fig. 5);

(ii) Poorly-crystallized illite shown by a larger peak at $1.01 \mathrm{~nm}$ (width at mid-height ranging from 0.6 to $0.8^{\circ}$ depending upon the position and the volume considered);

(iii) Chlorite, shown by the persistence of a narrow peak at $1.4 \mathrm{~nm}$ after treatment by ethylene glycol (Fig. 5 and Fig. 6). The collapse of this peak after heating at $520^{\circ} \mathrm{C}$ evidences chlorites rich in Fe rather than hydroxy-interlayered vermiculites (Tamura, 1957). The presence of chlorite is moreover confirmed by the peaks at 0.7 (overlapping with kaolinite), 0.47 and $0.35 \mathrm{~nm}$ in the different soil volumes (Fig. 5).

(iv) A clay mineral containing swelling phases as shown by a peak varying in position from $1.3 \mathrm{~nm}$ under $\mathrm{Mg}$-saturated conditions (data not shown) to $1.4 \mathrm{~nm}$, at position 60 , or even $1.61 \mathrm{~nm}$, at position 400, as glycol-treated (Fig. 6). Its width at mid-height is always larger than $1^{\circ}$ (Fig. 6). This mineral is identified as an illite-smectite mixed layer (IS) with different proportion in smectite depending on the distance to the drain rather than vermiculite or hydroxyl-interlayered smectite that normally should not swell over $1.6 \mathrm{~nm}$.

This complex silicate composition of lutum is in very good agreement with that described by Jamagne et al. (1984) in Albeluvisols of Northern France developed in loess.

\subsubsection{Selectivity of the eluviation process}

The main change in clay mineral composition, with the distance to the drain, is the presence, at position 60 , of chlorites - as shown by a well-expressed peak at $1.4 \mathrm{~nm}$ after treatment with ethylene glycol - whereas this peak is only weakly present at position 400 (Fig. 6). Another 
important change concerns the evolution of the swelling minerals. The interstratified illitesmectite peak is at $1.61 \mathrm{~nm}$ for position 400 and at $1.4 \mathrm{~nm}$ for position 60 (Fig. 6). As observed on oriented glycol-treated slides, this change is not related to a change in the interlayer cation as was observed by Pernes-Debuyser et al. (2003) for potassium fertilizer but likely to different proportions of smectites in the IS inducing different swelling. Furthermore, the intensity of the band attributed to IS decreased in the lutum of the ochre volumes of the E\&Bt-horizon with the distance to the drain (Fig. 6). On the opposite, the intensity of the band corresponding to chlorite increased relatively to other clays species as the distance to the drain decreased (Fig. 6). Similarly, the quartz concentrations in the lutum fraction of the ochre soil

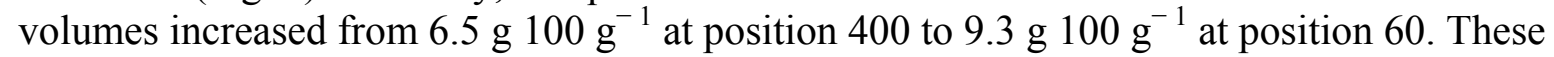
results suggest a preferential elimination of the interstratified minerals rich in smectites with respect to those rich in illites and other minerals present in the lutum.

The particle-size of smectites and interstratified illite-smectite was found to be generally smaller than that of illites and much smaller than that of quartz and chlorite in relatively similar soils ([De Coninck et al., 1976] and [Hardy et al., 1999]). The preferential elimination of smectites and interstratified illite-smectite would thus be related to the particle-size selectivity of the eluviation process. Indeed this process is known to not affect, or less so, the coarser minerals that are then relatively enriched ([De Coninck et al., 1976], [Jamagne et al., 1984] and [Hardy et al., 1999]). This result is coherent with the work by Mercier et al. (2000), who identified smectites, most commonly interstratified with illite, as one of the major constituents of suspended load of drains of a Luvisol.

The sequential extractions show that the quantities of iron in the ferrihydrite, goethite and clay fractions of the ochre soil volumes decrease of about $35 \%$ from position 400 to position 60 . This suggests that Fe removal is mostly caused by an intensification of the eluviation process, rather than by redox processes that would mainly affect oxides. This hypothesis agrees with the observations by Mercier et al. (2000), who showed that the particulate matter lost during agricultural drainage of a Luvisol consist in well- and poorly-crystallized iron oxides, commonly smaller than $200 \mathrm{~nm}$, as well as aggregates of phyllosilicates and iron oxides.

\subsection{Modelling the impact of eluviation and redox processes on different mineralogical forms of iron and manganese: variability of this impact with the distance to the drain}

Mass-balance modelling shows that Mn oxide quantities increase within the two horizons with decreasing distance to the drain (Fig. 7). This is mainly due to the formation of black volumes whose abundance also increases with decreasing distance to the drain (Table 2) and, to a lesser extent, to the precipitation of Mn oxides in the ochre and pale-brown volumes of the E\&Bt-horizon (Fig. 7). On the opposite, about $6 \mathrm{~g} \mathrm{~m}^{-2}$ of Mn is lost from ferrihydrite whatever the distance to the drain. This is due to the differentiation of the white-grey volumes. The Mn associated with goethite or clays was lost increasingly as the distance to the drain decreased (Fig. 7). These two opposite trends resulted in increasingly more Mn stored in Mn oxides relatively to the other forms of Mn with decreasing distance from the drain. In the initial soil material, i.e. the ochre volumes of the Bt-horizon, Mn oxides were the third most abundant form of $\mathrm{Mn}\left(13.2 \mathrm{~g} \mathrm{~m}^{-2}\right)$ after the ferrihydrite $\left(45 \mathrm{~g} \mathrm{~m}^{-2}\right)$ and the clays $\left(25.5 \mathrm{~g} \mathrm{~m}^{-2}\right.$, Fig. 7). Long-term formation processes (position 400, Fig. 7) resulted in Mn being contained as much in oxides as ferrihydrite with a gain of about $29 \mathrm{~g} \mathrm{~m}^{-2}$ of $\mathrm{Mn}$ as Mn oxides and a loss of $7 \mathrm{~g} \mathrm{~m}^{-2}$ of $\mathrm{Mn}$ from ferrihydrite. Agricultural drainage (position 60, Fig. 7), increases the quantity of Mn contained in the Mn oxides (about $190 \mathrm{~g} \mathrm{~m}^{-2}$ ) to about four times that of ferrihydrite (about $50 \mathrm{~g} \mathrm{~m}^{-2}$ ). 
The mass of $\mathrm{Fe}$ in the ferrihydrite, goethite and clay fractions decreased from the reference state (ochre volumes from the Bt-horizon) to the two positions 400 and 210 (Fig. 8). This decrease ranges from about $500 \mathrm{~g} \mathrm{~m}^{-2}$ for the clays to about $3000 \mathrm{~g} \mathrm{~m}^{-2}$ for the ferrihydrite. It is further enhanced from these two positions to position 60. The losses in Fe reached thus 6400,5700 and $1500 \mathrm{~g} \mathrm{~m}^{-2}$ for respectively the ferrihydrite, goethite and clays (Fig. 8). This increase of Fe losses at $60 \mathrm{~cm}$, and in particular the three-fold increase of Fe losses as clay, underlines the increase in intensity of the eluviation process as a result of soil drainage.

The mass-balance modelling shows that the formation of black volumes induces the appearance of iron in association with Mn oxides. This mineralogical form of Fe is specific to the black volumes and initially did not exist. This phenomenon, however, is negligible in comparison to the loss of other Fe forms. In the same manner, ferrihydrite precipitates along the formation of black volumes. This only leads to negligible Fe gains when compared to the exports related to the differentiation of the white-grey volumes (Fig. 8). At position 60, the black volumes of the E\&Bt-horizon have lost goethite but no ferrihydrite. This shows that the precipitation of ferrihydrite in the black volumes compensates the losses related to the intensification of the eluviation process.

As a conclusion the formation of black volumes with decreasing distance to the drain is the main process at the origin of the changes in the mineralogical forms of manganese but has only a slight impact on the evolution of the different forms of iron. These last ones essentially evolve due to an increase in the eluviation process. Eluviation being only slightly selective for the different forms of iron, their relative abundance does not change in terms of the distance to the drain at the scale of the two horizons.

Finally, from these data and considering that the lost clays were mostly smectites, as was shown by XRD analysis of the lutum, the lost masses of goethite, ferrihydrite and smectites were calculated (Table 4) and compared to the lost mass of lutum (Montagne, 2006). Both the sum of goethite, ferrihydrite and smectite losses, and the loss of lutum are of the same order of magnitude. This suggests that lutum losses are effectively related to losses of goethite, ferrihydrite and smectites (or other 2:1 clay types close to smectite), as opposed to chlorite, quartz and kaolinite. Smectite loss represents about $80 \%$ of total exported minerals (Table 4).

\subsection{Temporal succession of the eluviation and redox processes}

We showed, using the Fe/Mn ratios in goethite and ferrihydrite of the ochre and the black volumes, that black volumes result, as far as forms of iron are concerned, in the cementation by ferrihydrite of the soil matrix. Goethite and clays were thus inherited.

Thermal-analysis quantification of the abundance of clay minerals in the black and ochre volumes confirms that the quantities of clay minerals cemented in the black volumes are similar to those found in the ochre volumes, regardless of the distance to the drain (Fig. 9). They also showed that the abundance of clay minerals decreased in the ochre and the black soil volumes from the two positions 400 and 210 to position 60 , which is in very good agreement with the results of mass-balance modelling and XRD analysis and results from the drainage impact.

The decrease of the quantities of clay minerals and that of the quantities of $\mathrm{Fe}$ in the clays fraction of the black volumes at position 60 , thus indicates that the cementing of the soil 
matrix through preferential precipitation of ferrihydrite and Mn oxides occurs after the evolution of the ochre volumes through the impact of the eluviation process.

It seems therefore that the removal of goethite, ferrihydrite and smectites, in answer to the intensification of the eluviation process, took place very shortly after the drainage network was installed and then decreased in intensity. Turtola and Paajanen (1995) already described this type of evolution in the eluviation process, in response to soil drainage. They indeed measured a very strong increase in the export of particulate matter following the renewal of a drainage network and then a slow decrease over time in the matter losses (Turtola and Paajanen, 1995).

\section{Conclusions}

Mass-balance modelling in combination with a space-for-time substitution generally suffers two main limitations:

1. the difficulty to select soils having similar topography, parent material and climate, the latest being constant through space and time. This is a required condition in order to be able to interpret the observed changes in the soil solid phase as a result of time.

2. the age of the soil profiles must be known, at least in one position; relative ages among the different positions being sometime sufficient. However, soil ages are difficult to rate, and their uncertainty often increased with the age of the soil.

The studied case is ideal to apply this kind of approach as the age of the drainage network is known with accuracy and the studied soil profiles are located on a sufficiently short distance (i.e. some meters) that we can consider that the heterogeneities in terms of soil parent material, climate and topography are highly limited. We can thus interpret soil changes as a result of drainage through time with a reasonably good level of confidence.

Both redox and eluviation processes are significantly impacted by drainage with resulting mineralogical changes that are of a same order of magnitude than those resulting from the long-term soil formation. Changes in redox conditions result in increasing precipitation of $\mathrm{Mn}$ oxides and Mn-rich ferrihydrite with decreasing distance to the drain. As a consequence the main $\mathrm{Mn}$ form is Mn-rich ferrihydrite before drainage and becomes Mn oxides after 16 years of subsurface drainage. The enhanced eluviation results in the removal of most of the swelling clays-minerals and of more than one third of the Fe oxides at the immediate vicinity of the drain. These changes occur over a maximum period of time of 16 years for the redox processes but are thought to be even faster for the eluviation process that seems to be active in the studied soil type only during the first years after the drainage network installation. As a conclusion, a change in environmental conditions, like the intensity and the velocity of water fluxes, sufficiently modifies soil processes - as eluviation and redox - to induce significant changes in the soil mineralogical composition even over period of time as short as some tens of years.

\section{Acknowledgments}

This work was funded by the Région Centre. H.M. Kluijver translated the original French version into English. The authors acknowledge C. Le Lay for technical assistance during the field sampling and laboratory work. The authors also gratefully acknowledge the two 
anonymous reviewers for their help in improving the quality and the clarity of the present research paper.

\section{References}

Augusto et al., 2000 L. Augusto, M.P. Turpault and J. Ranger, Impact of forest tree species on feldspar weathering rates, Geoderma 96 (3) (2000), pp. 215-237

Baize and Voilliot, 1988 D. Baize and J.P. Voilliot, Notice de la carte des sols de l'Yonne à 1/50000, feuille Joigny. Station agronomique de l'Yonne, Auxerre, France (1988) 142 pp.. Benitez and Dubois, 1999 L.N. Benitez and J.-P. Dubois, Evaluation of the selectivity of sequential extraction procedures applied to the speciation of cadmium in soils, International Journal of Environmental Analytical Chemistry 74 (1-4) (1999), pp. 289-303. Bidwell and Hole, 1965 O.W. Bidwell and F.D. Hole, Man as a factor of soil formation, Soil Science 99 (1965), pp. 65-72.

Boag et al., 1997 B. Boag, L.F. Palmer, R. Neilson, R. Legg and S.J. Chambers, Distribution, prevalance and intensity of earthworm populations in arable land and grassland in Scotland, Annals of Applied Biology 130 (1) (1997), pp. 153-165

Brimhall et al., 1991 G.H. Brimhall, C.J. Lewis, C. Ford, J. Bratt, G. Taylor and O. Warin, Quantitative geochemical approach to pedogenesis: importance of parent material reduction, volumetric expansion, and eolian influx in lateritization, Geoderma 51 (1-4) (1991), pp. 5191.

Brinkman, 1979 R. Brinkman, Ferrolysis, a Soil-forming Process in Hydromorphic

Conditions, Center for Agricultural Publishing and Documentation, Wageningen, Netherlands (1979).

Burt and Alexander, 1996 R. Burt and E.B. Alexander, Soil development on moraines of Mendenhall Glacier, southeast Alaska. 2. Chemical transformations and soil micromorphology, Geoderma 72 (1) (1996), pp. 19-36

Cadastre, 1828 Cadastre, 1828. Plan cadastral parcellaire au $1 / 4000^{\mathrm{e}}$ de la commune de Chevillon, canton de Charny, arrondissement de Joigny, département de l'Yonne Archives départementales de l'Yonne.

Caravaca et al., 2002 F. Caravaca, G. Masciandaro and B. Ceccanti, Land use in relation to soil chemical and biochemical properties in a semiarid Mediterranean environment, Soil and Tillage research 68 (2002), pp. 23-30.

Cattle et al., 1994 S.R. Cattle, A.J. Koppi and A.B. McBratney, The effect of cultivation on the properties of a Rhodoxeralf from the wheat/sheep belt of new South Wales, Geoderma $\mathbf{6 3}$ (1994), pp. 215-225.

Chantigny, 2003 M.H. Chantigny, Dissolved and water-extractable organic matter in soils: a review on the influence of land use and management pratices, Geoderma 113 (3-4) (2003), pp. 357-380.

Ciesielsky et al., 1997 H. Ciesielsky, N. Proix and T. Sterckeman, Détermination des incertitudes liées à une méthode de mise en solution des sols et sédiments par une étude interlaboratoire, Analusis 25 (1997), pp. 188-192.

Cornell and Schwertmann, 1996 R.M. Cornell and U. Schwertmann, The Iron Oxides, VCH, Weinheim, Germany (1996) 573 pp..

Cornu et al., 1995 S. Cornu, Y. Lucas, T. Desjardins and S. Nietsch, Mise en évidence des vitesses d'altération des minéraux du sol en conditions ferrallitiques. Méthode des minéraux tests, C. R. Acad. Sci. Paris, série IIa 321 (1995), pp. 311-316.

Cornu et al., 2006 S. Cornu, S. Salvador-Blanes, M. Hardy, B. Clozel, C. Crouzet, N. Proix and A. Guerin, Location of trace elements in unpolluted soils by a combined method, Communications in Soil Science and Plant Analysis 37 (7-8) (2006), pp. 1077-1101. 
De Coninck et al., 1976 F. De Coninck, J.C. Favrot, R. Tavernier and M. Jamagne, Dégradation dans les sols lessivés hydromorphes sur matériaux argilo-sableux: exemple des sols de la nappe détritique bourbonnaise (France), Pédologie 26 (2) (1976), pp. 105-151.

Driessen et al., 2001 In: P. Driessen, J. Deckers, O. Spaargaren and F. Nachtergaele, Editors, Lecture Notes on the Major Soils of the World, FAO, Rome (2001) 334 pp..

Egli and Fitze, 2000 M. Egli and P. Fitze, Formulation of pedologic mass balance based on immobile elements: a revision, Soil Science 165 (5) (2000), pp. 437-443.

Gerlach et al., 2004 R. Gerlach, M.W.I. Schmidt, H. Baumewerd-Schmidt and K. van den Borg, Chernozemic Soils in the Rhineland as Relics of Prehistoric Agriculture, Eurosoil, Albert-Ludwigs-Universität Freiburg, Freiburg Germany (2004), p. 165.

Goulding and Blake, 1998 K.W.T. Goulding and L. Blake, Land use, liming and the mobilization of potentially toxic metals, Agriculture, Ecosystems and Environment 67 (2-3) (1998), pp. 135-144.

Hall et al., 1996a G.E.M. Hall, J.E. Vaive, R. Beer and M. Hoashi, Selective leaches revisited, with emphasis on the amorphous Fe oxyhydroxide phase extraction, Journal of Geochemical Exploration 56 (1) (1996), pp. 59-78

Hall et al., 1996b G.E.M. Hall, J.E. Vaive, A.I. MacLaurin and M. Hoashi, Selective leaching of the labile organic component of humus and soils with sodium pyrophosphate solution, Bulletin of the Geological Survey of Canada 426 (1996), pp. 201-213.

Han and Banin, 1995 F.X. Han and A. Banin, Selective sequential dissolution techniques for trace metals in arid-zone soils: the carbonate dissolution step, Communications in Soil Science and Plant Analysis 26 (3-4) (1995), pp. 553-576.

Hardy, 1992 M. Hardy, X-ray diffraction measurement of the quartz content of clay and silt fractions in soils, Clay Minerals 27 (1) (1992), pp. 47-55.

Hardy et al., 1999 M. Hardy, M. Jamagne, F. Elsass, M. Robert and D. Chesneau, Mineralogical development of the silt fractions of a Podzoluvisol on loess in the Paris Basin (France), European Journal of Soil Science 50 (3) (1999), pp. 443-456

Jamagne, 1978 M. Jamagne, Soil-forming processes in a progressive evolutionary sequence on loessial silty formation in a cold and humid temperate zone, Comptes Rendus

Hebdomadaires des Séances de l'Académie des Sciences, Paris 286 (1) (1978), pp. 25-27.

Jamagne et al., 1984 M. Jamagne, F. De Coninck, M. Robert and J. Maucorps, Mineralogy of clay fractions of some soils on loess in northern France, Geoderma 33 (4) (1984), pp. 319342.

Jeanroy and Guillet, 1981 E. Jeanroy and B. Guillet, The occurrence of suspended ferruginous particles in pyrophosphate extracts of some soil horizons, Geoderma 26 (1-2) (1981), pp. 95105.

Jenny, 1941 H. Jenny, Factors of Soil Formation, Mc Graw-Hill, New-York (1941) 281 pp.. Jersak et al., 1997 J. Jersak, R. Amundson and G. Brimhall Jr., Trace metal geochemistry in spodosols of the northeastern United States, Journal of Environmental Quality 26 (2) (1997), pp. 511-521.

Jussy et al., 2002 J.H. Jussy, W. Koerner, E. Dambrine, J.L. Dupouey and M. Benoît, Influence of former agricultural land use on net nitrate production in forest soil, European Journal of soil science 53 (2002), pp. 367-374.

Karathanasis and Harris, 1994 A.D. Karathanasis and W.G. Harris, Quantitative thermal analysis of soil material. In: A.J.E. and L.W. Zelazny, Editors, Quantitative Methods in Soil Mineralogy, SSSA Miscellaneous Publication, Madison (1994), pp. 360-411.

Kleber et al., 2003 M. Kleber, J. Rossner, C. Chenu, B. Glaser, H. Knicker and R. Jahn, Prehistoric alteration of soil properties in a Central German chernozemic soil: in search of pedologic indicators for prehistoric activity, Soil Science 168 (2003), pp. 292-306. 
Langhor, $2001 \mathrm{R}$. Langhor, L'anthropisation du paysage pédologique agricole de la Belgique depuis le Néolithique ancien - Apports de l'archéopédologie, Etude et Gestion des Sols $\mathbf{8}$ (2001), pp. 103-118.

Lanson, 1993 B. Lanson, DECOMPXR, X-ray Decomposition Program, ERM (Société Etudes Recherche Matériaux), Poitiers, France (1993).

Lanson, 1997 B. Lanson, Decomposition of experimental X-ray diffraction patterns (profile fitting): a convenient way to study clay minerals, Clays and Clay Minerals 45 (2) (1997), pp. $132-146$.

Leica Geosystems GIS and Mapping LLC, 2003 Leica Geosystems GIS and Mapping LLC, Erdas Imagine, Atlanta, Georgia (2003).

Lima et al., 2002 H.N. Lima, C.E.R. Schaefer, J.W.V. Mello, R.J. Gilkes and J.C. Ker, Pedogenesis and pre-Colombian land use of "Terra Preta Anthrosols" ("Indian black earth") of western Amazonia, Geoderma 110 (2002), pp. 1-17.

Liu et al., 2002 F. Liu, C. Colombo, P. Adamo, J.Z. He and A. Violante, Trace elements in manganese-iron nodules from a Chinese alfisol, Soil Science Society of America Journal 66 (2) (2002), pp. 661-670.

Lucas et al., 1996 Y. Lucas, D. Nahon, S. Cornu and F. Eyrolle, Genèse et fonctionnement des sols en milieu équatorial, C. R. Acad. Sci. Paris, série IIa 322 (1996), pp. 1-16.

Manceau et al., 2003 A. Manceau, N. Tamura, R.S. Celestre, A.A. MacDowell, N. Geoffroy, G. Sposito and H.A. Padmore, Molecular-scale speciation of $\mathrm{Zn}$ and $\mathrm{Ni}$ in soil

ferromanganese nodules from loess soils of the Mississippi basin, Environmental Science and Technology 37 (1) (2003), pp. 75-80

McKenzie, 1977 R.M. McKenzie, Manganese oxides and hydroxides. In: J.B. Dixon and S.B. Weed, Editors, Minerals in Soil Environments, Soil Science Society of America, Madison, Wisconsin USA (1977), pp. 181-193.

Mercier et al., 2000 P. Mercier, L. Denaix, M. Robert and G. De Marsily, Colloid transfer by subsurface drainage [Caracterisation des matières colloidales evacuées au cours du drainage agricole: Incidence sur l'évolution pédogenétique des sols], Comptes Rendus de l'Academie de Sciences - Serie IIa: Sciences de la Terre et des Planetes 331 (3) (2000), pp. 195-202. Monnier et al., 1973 G. Monnier, P. Stengel and J.C. Fiès, A method to measure the bulk density of soil aggregates, Application to the analysis of the soil porosity. Annales

Agronomiques 24 (1973), pp. 533-545.

Montagne, 2006 D. Montagne, Impact de la mise en culture et du drainage sur l'évolution récente des sols: cas des Luvisols dégradés de l'Yonne, Université d'Orléans, Orléans (2006) $210 \mathrm{pp}$.

Montagne et al., 2007 D. Montagne, I. Cousin, L. Le Forestier, J. Daroussin and S. Cornu, Quantification of soils volumes in the Eg\&Bt-horizon of an Albeluvisol using image analysis, Canadian Journal of Soil Science 87 (2007), pp. 51-59.

Pedro et al., 1978 G. Pedro, M. Jamagne and J.C. Begon, Two routes in genesis of strongly differentiated acid soils under humid, cool-temperate conditions, Geoderma 20 (1978), pp. 173-189.

Pomerol, 1988 B. Pomerol, Carte géologique de la France (1/50000), feuille Courtenay (366), BRGM, Orléans (1988).

Quideau and Bockeim, 1996 S.A. Quideau and J.G. Bockeim, Vegetation and cropping effects on pedogenetic processes in a sandy prairie soil, Soil Sci. Soc. Am. J. 60 (1996), pp. 536-545.

Richard et al., 2001 G. Richard, I. Cousin, J.F. Sillon, A. Bruand and J. Guerif, Effect of compaction on the porosity of a silty soil: influence on unsaturated hydraulic properties, European Journal of Soil Science 52 (1) (2001), pp. 49-58 
Richter and Markewitz, 2001 D.D. Richter and D. Markewitz, Understanding Soil Change. Soil Sustainability Over Millennia, Centuries and Decades, Cambridge University Press, Cambridge, UK (2001) 255 pp..

Robert and Tessier, 1974 M. Robert and D. Tessier, Méthode de préparation des argiles des sols pour des études minéralogiques, Ann. agron. 25 (6) (1974), pp. 859-882.

Schwertmann and Taylor, 1977 U. Schwertmann and R.M. Taylor, Iron oxides. In: J.B. Dixon and S.B. Weed, Editors, Minerals in Soil Environments, Soil Science Society of America, Madison, Wisconsin, USA (1977), pp. 145-180.

Sposito, 1989 G. Sposito, The Chemistry of Soils, Oxford University Press (1989) 277 pp.. Stichting voor Bodemkaartering, 1965 In: Stichting voor Bodemkaartering, Editor, De Bodem van Nederland: Toelichting bij de Bodemkaart van Nederland schaal 1:200 000, Stichting voor Bodemkaartering, Wageningen (1965) 292 pp..

Stolt et al., 1994 M.H. Stolt, C.M. Ogg and J.C. Baker, Strongly contrasting redoximorphic patterns in Virginia Valley and Ridge paleosols, Soil Science Society of America Journal 58 (2) (1994), pp. 477-484.

Tamura, 1957 T. Tamura, Identification of the $14 \AA$ clay mineral component, American Mineralogist 42 (1957), pp. 107-110.

Tessier et al., 1979 A. Tessier, P.G.C. Campbell and M. Bisson, Sequential extraction procedure for the speciation of particulate trace metals, Analytical Chemistry 51 (7) (1979), pp. 844-851.

Turtola and Paajanen, 1995 E. Turtola and A. Paajanen, Influence of improved subsurface drainage on phosphorus losses and nitrogen leaching from a heavy clay soil, Agricultural Water Management 28 (4) (1995), pp. 295-310.

Van Ranst and De Coninck, 2002 E. Van Ranst and F. De Coninck, Evaluation of ferrolysis in soil formation, European Journal of Soil Science 53 (4) (2002), pp. 513-519

Wilkinson et al., 2005 M.T. Wilkinson, J. Chappell, G.S. Humphreys, K. Fifield, B. Smith and P. Hesse, Soil production in heath and forest, Blue Mountains, Australia: influence of lithology and palaeoclimate, Earth Surface Processes and Landforms 30 (8) (2005), pp. 923934.

Yaalon and Yaron, 1966 D.H. Yaalon and B. Yaron, Framework for man-made soil changes: an outline of metapedogenesis, Soil Science 102 (4) (1966), pp. 272-277. 


\section{Figures and Tables}

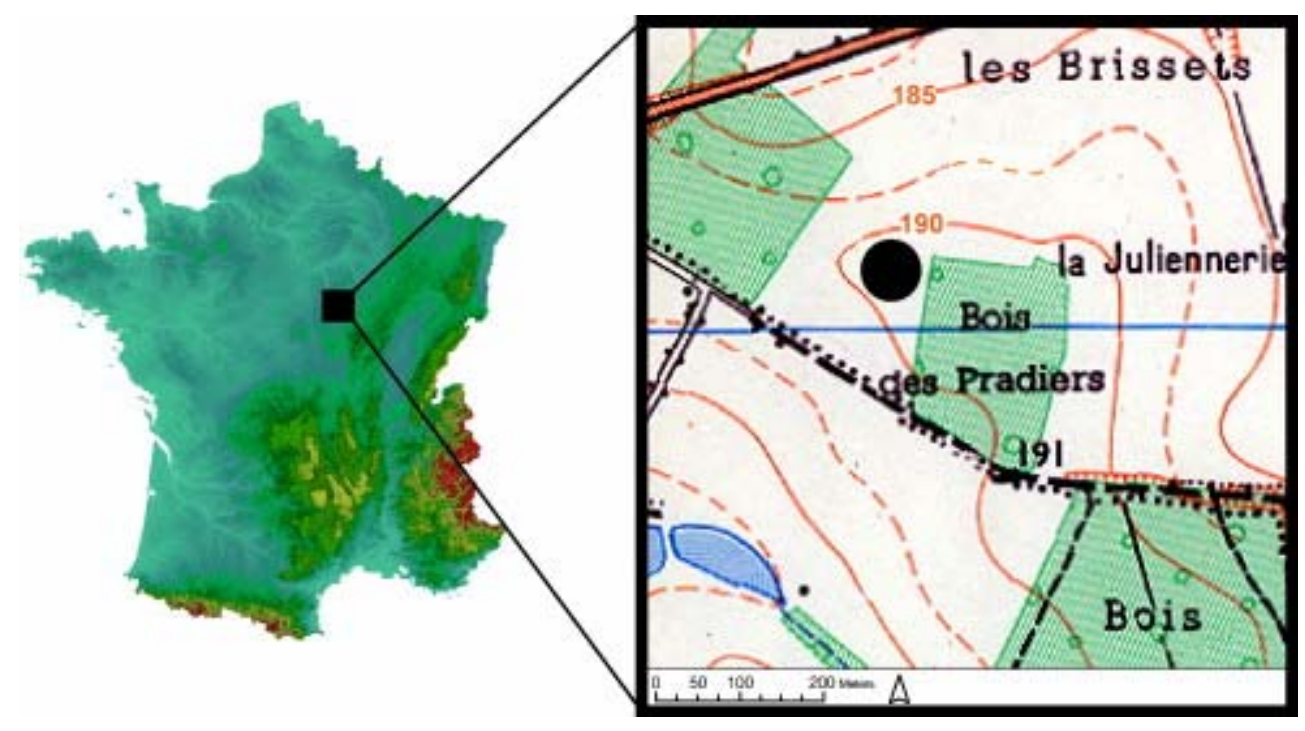

Fig. 1. Location of the studied site in France. The soil trench wad dug on the top of a plateau in a field called "Les Brissets".

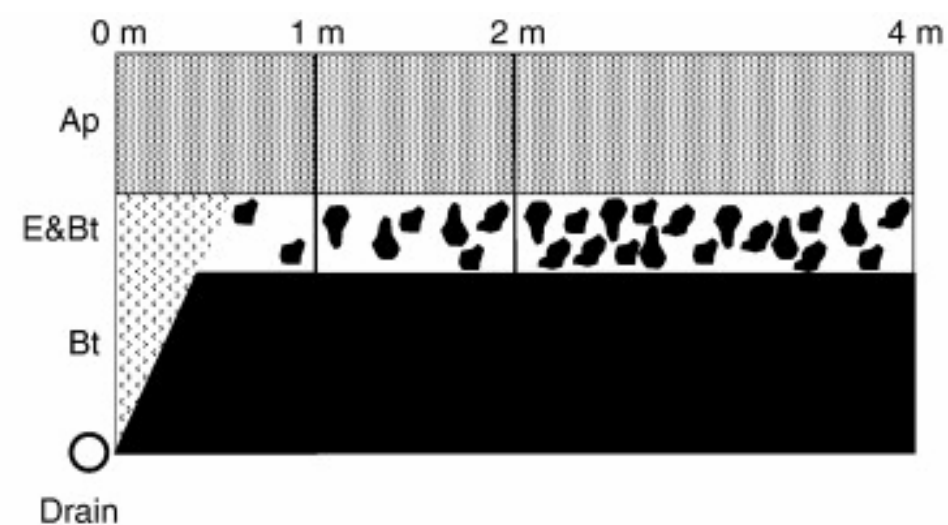

Zone disturbed by subsoiling operations

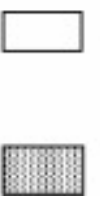

Silty soil volumes of white-grey and paleClayey soil volumes of
ochre colour brown colours

\section{Surface ploughed horizon}

Fig. 2. Schematic representation of the evolution of the relative abundance of the different soil volumes with the distance to the drain. Distances (in $\mathrm{m}$ ) indicate of the position of the studied soil profiles. For simplicity, the black soil volumes in both horizons and the white-grey, the pale-brown and the brow-salmon soil volumes in the Bt-horizon were not represented. 


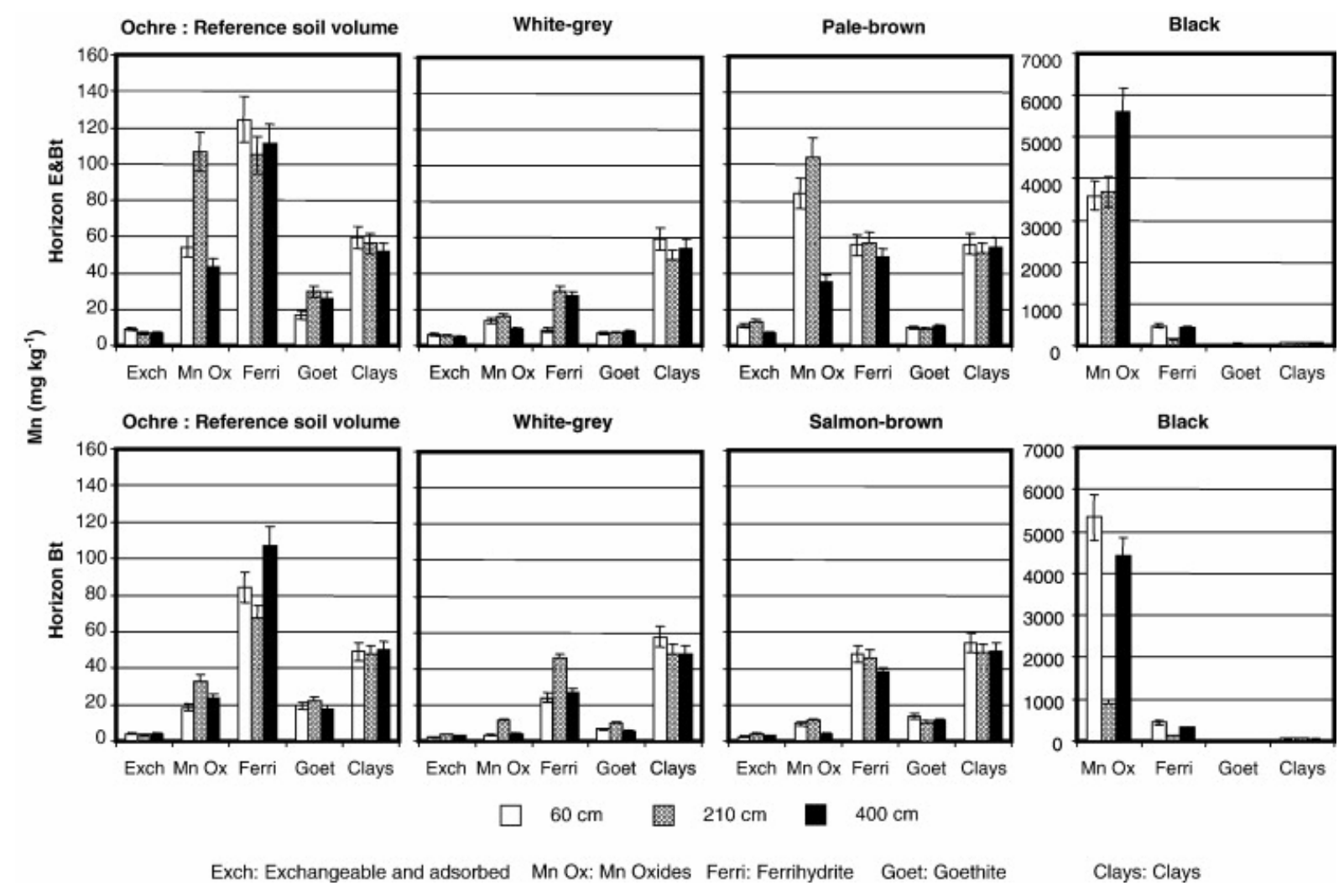

Fig. 3. Quantities of Mn extracted by the different steps of the sequential extraction for the different soil volumes and distances to the drain. Error bars represent $\pm 10 \%$ of the measured quantities.

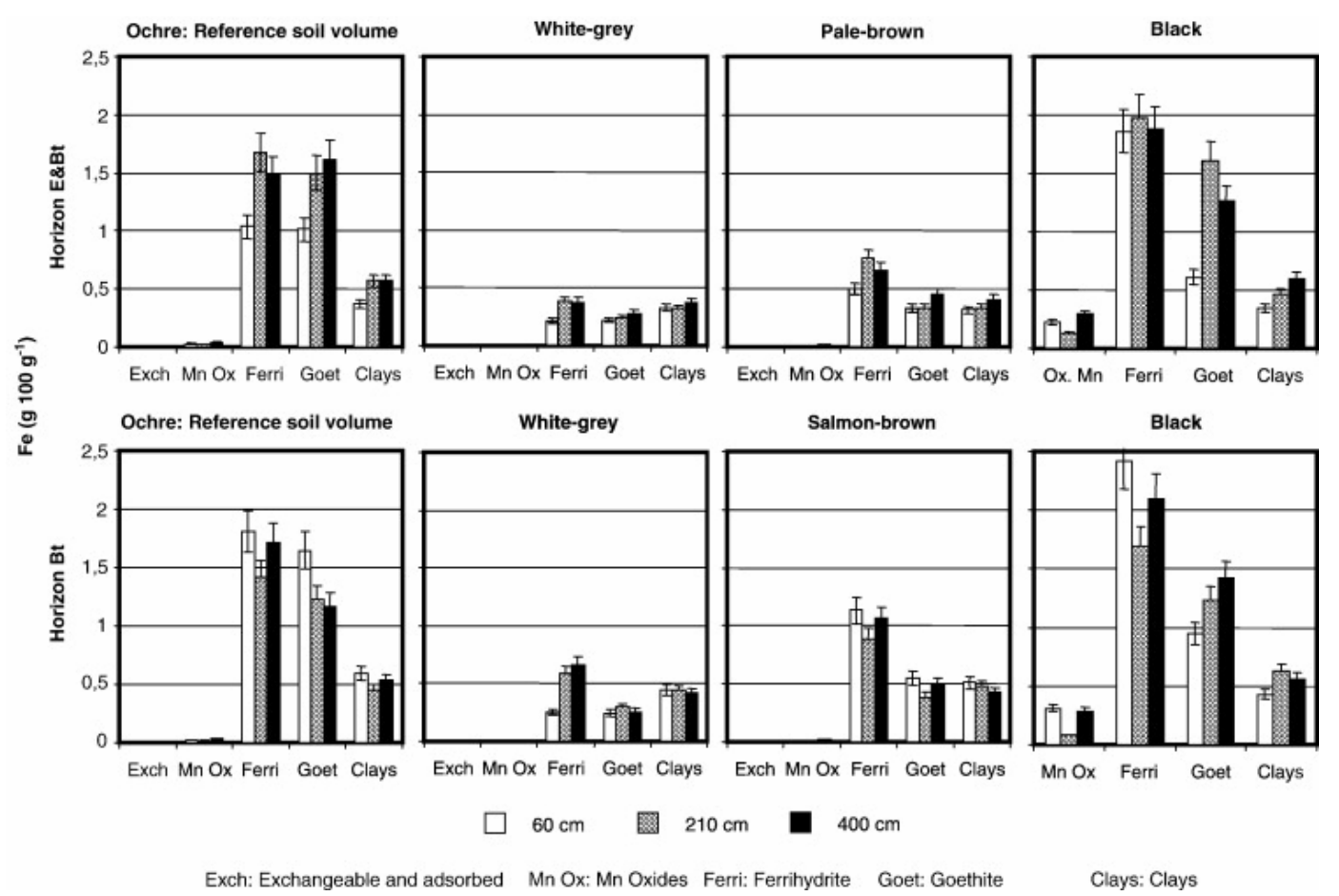

Fig. 4. Quantities of Fe extracted by the different steps of the sequential extraction for the different soil volumes and distances to the drain. Error bars represent $\pm 10 \%$ of the measured quantities. 

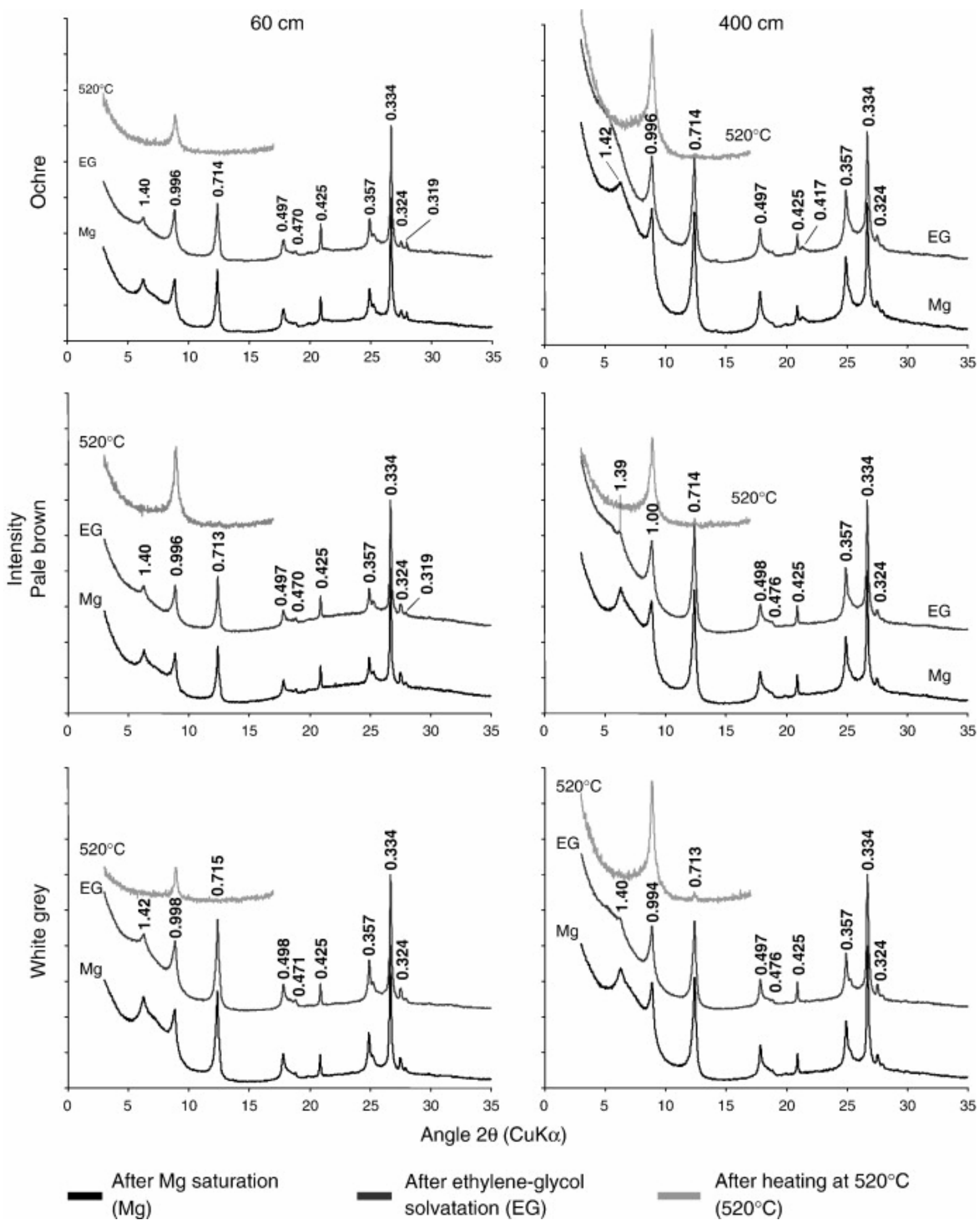

Fig. 5. XRD spectra of the lutum after $\mathrm{Mg}$ saturation $(\mathrm{Mg})$, treatment with ethylene glycol (EG) and heating at $520^{\circ} \mathrm{C}\left(520^{\circ} \mathrm{C}\right)$ for the different soil volumes of the E\&Bt-horizon at positions 60 and 400. The lattice distances (in $\mathrm{nm}$ ) were reported on the top of corresponding peaks. 

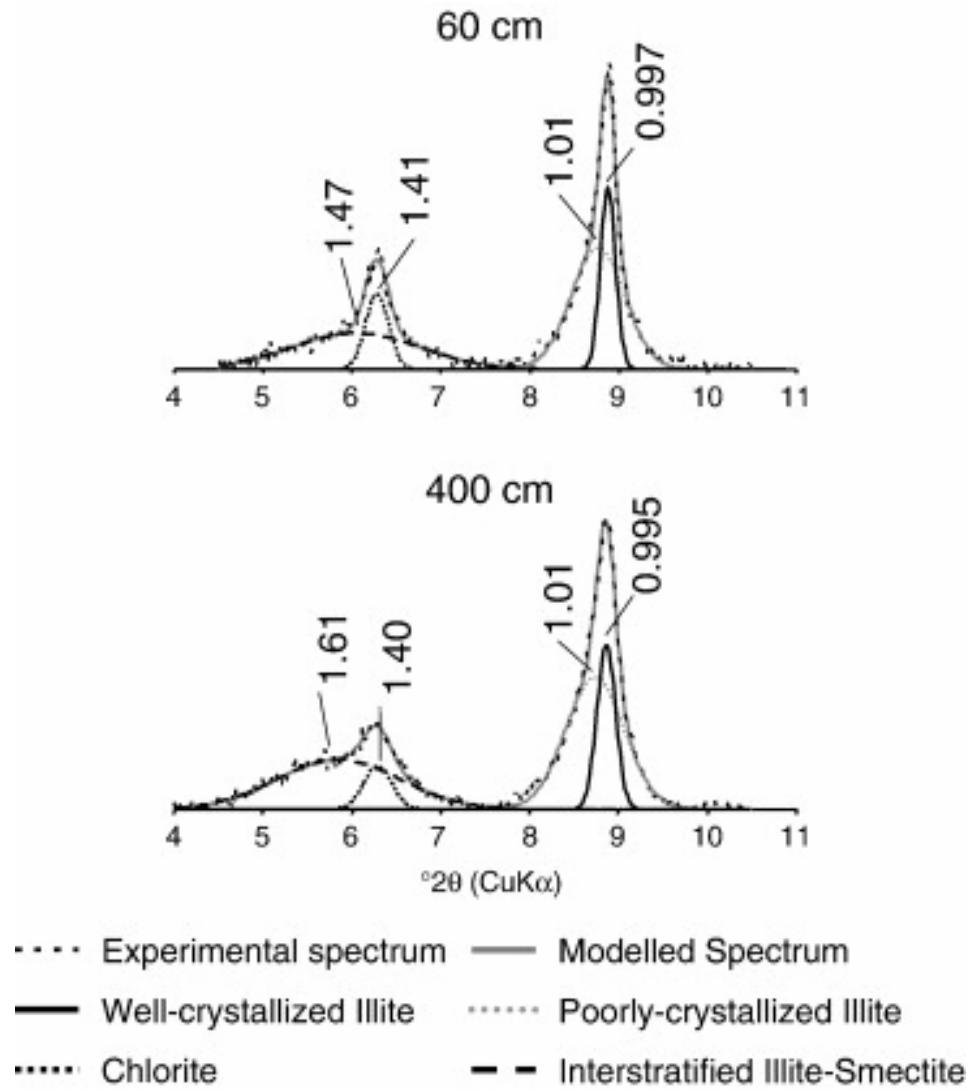

Fig. 6. XRD deconvolution patterns of the clay-fraction after treatment with ethylene glycol of the ochre soil volumes from the E\&Bt-horizon at positions 60 and 400 . The lattice distances (in $\mathrm{nm}$ ) were reported on the top of corresponding peaks. 


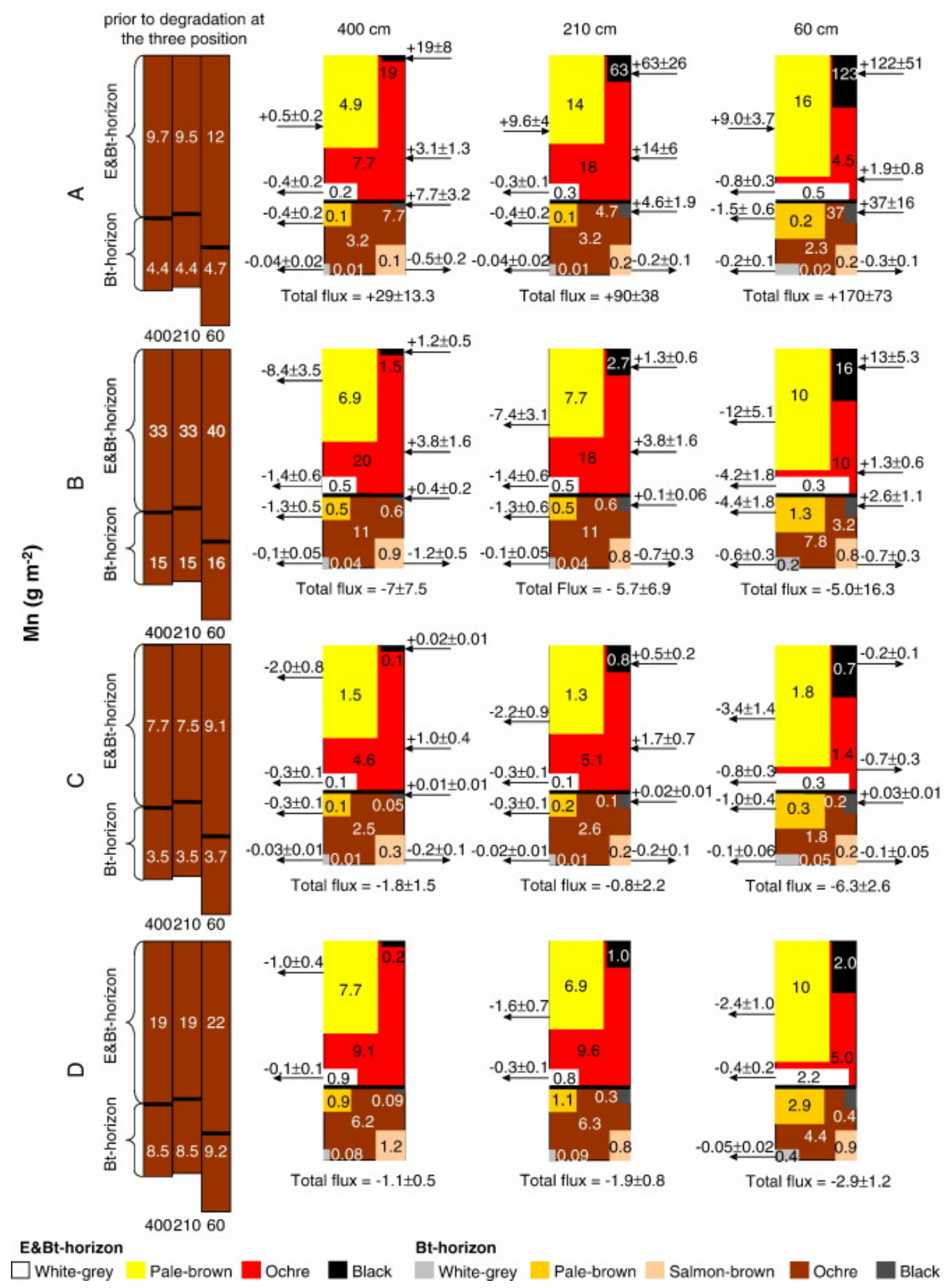

Fig. 7. Stocks and gains, or losses, of the different mineralogical forms of Mn using a massbalance model at positions 400, 210 and 60. A: Mn oxides; B: ferrihydrite; C: goethite; D: clays. The ochre soil volumes from the Bt-horizon were considered as reference material. The rectangles schematically showing the different soil volumes have an area proportional to their relative abundance. The numbers inside the rectangles indicate the stocks presently contained in the considered soil volume. Positive fluxes correspond to gains and negative fluxes to losses. The lack of an arrow indicates negligible flux. 


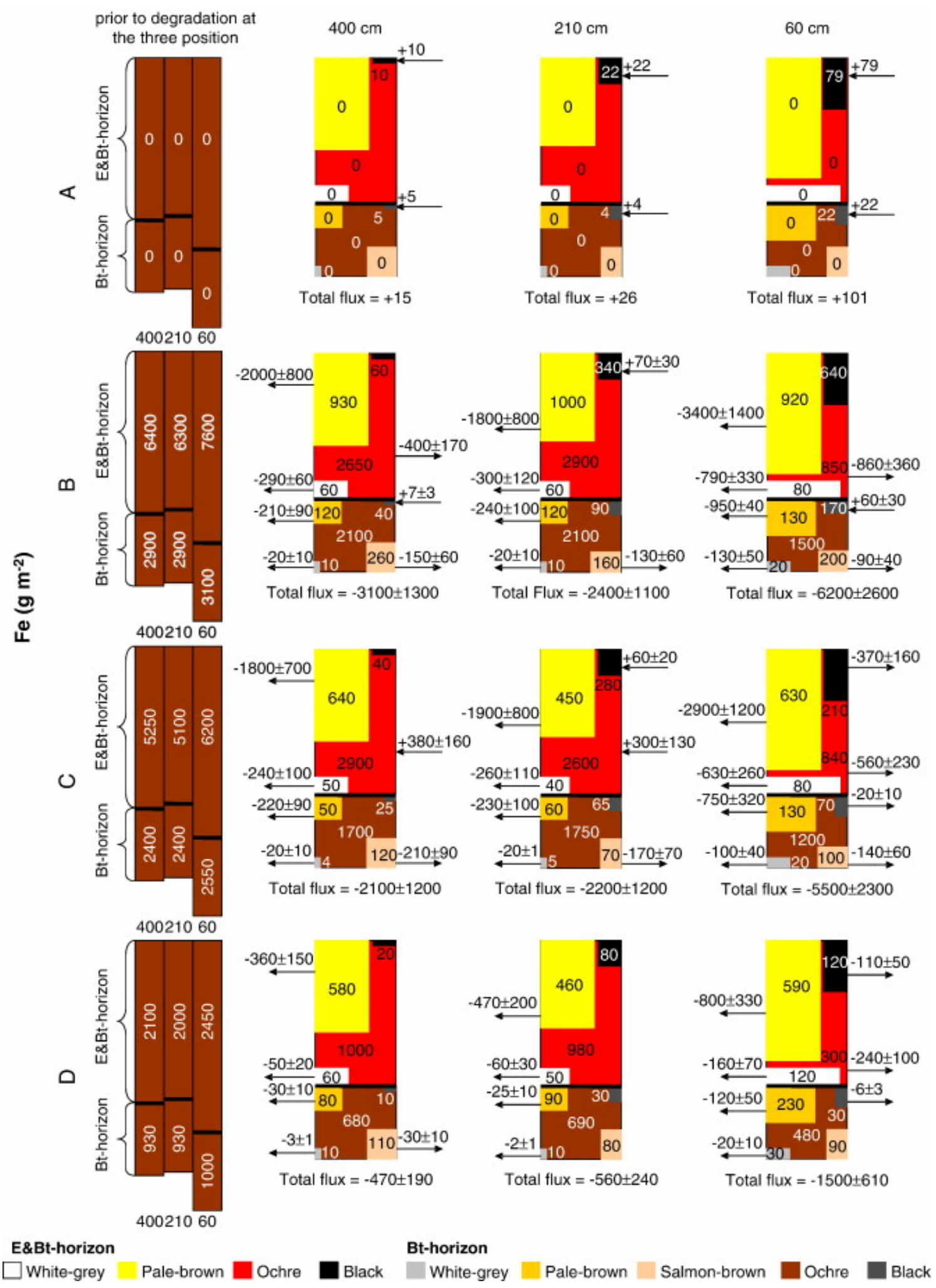

Fig. 8. Stocks and gains in or losses of the different mineralogical forms of Fe using a massbalance model at positions 400, 210 and 60. A: Mn oxides; B: ferrihydrite; C: goethite; D: clays. The ochre soil volumes from the Bt-horizon were considered as reference material. The rectangles schematically showing the different soil volumes have an area proportional to their relative abundance. The numbers inside the rectangles indicate the stocks presently contained in the considered soil volume. Positive fluxes correspond to gains and negative fluxes to losses. The lack of an arrow indicates negligible flux. 


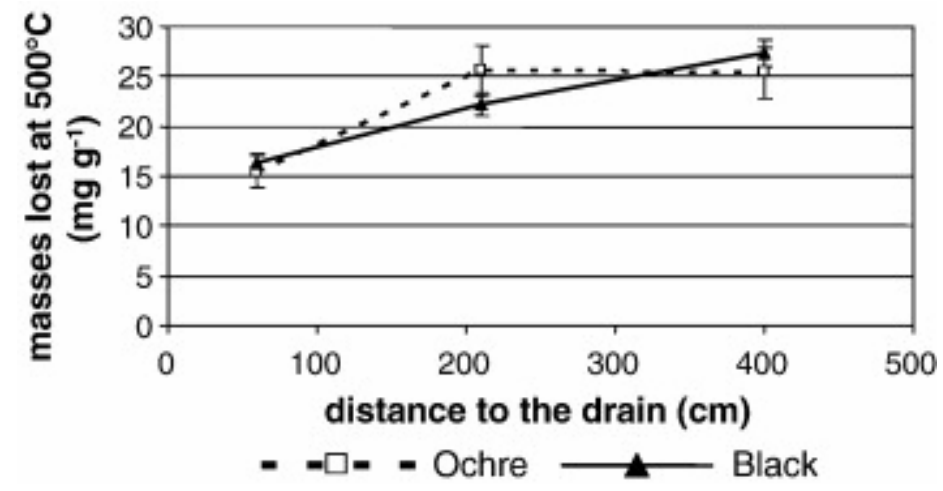

Fig. 9. Masses lost as a result of the dehydroxylation of clay minerals in the ochre and black soil volumes of the E\&Bt-horizon at 60,210 , and $400 \mathrm{~cm}$ from the drain. Error bars represent $\pm 10 \%$ of the measured masses. 
Table 1. : Main pedological properties of the different soil horizons as a function of the distance to the drain

\begin{tabular}{|c|c|c|c|c|c|c|c|}
\hline \multirow[t]{2}{*}{ Horizon } & \multirow[t]{2}{*}{$\begin{array}{l}\text { Depth } \\
\text { (cm) }\end{array}$} & \multicolumn{3}{|c|}{$\begin{array}{l}\text { Particle-size distribution (g } \\
\mathrm{kg}^{-1} \text { ) }\end{array}$} & \multirow[t]{2}{*}{$\underline{\mathbf{p H}}$} & \multirow[t]{2}{*}{$\begin{array}{l}\text { Organic C (g } \\
\left.\mathrm{kg}^{-1}\right)\end{array}$} & \multirow[t]{2}{*}{$\begin{array}{l}\operatorname{Iron}(\mathrm{g} \\
\left.\mathrm{kg}^{-1}\right)\end{array}$} \\
\hline & & $<2 \mu \mathrm{m}$ & $2-50 \mu \mathrm{m}$ & $\begin{array}{l}50- \\
2000 \mu \mathrm{m}\end{array}$ & & & \\
\hline \multicolumn{8}{|c|}{ Position 400} \\
\hline $\mathrm{Ap}$ & $10-20$ & 132 & 746 & 122 & 7.4 & 7.0 & 15 \\
\hline $\mathrm{E}$ & $25-35$ & 134 & 749 & 117 & 7.3 & 7.3 & 16 \\
\hline \multirow[t]{2}{*}{$\mathrm{E} \& \mathrm{Bt}$} & $35-45$ & 223 & 701 & 76 & 8.0 & 1.4 & 22 \\
\hline & $45-55$ & 288 & 642 & 70 & n.d. & n.d. & 27 \\
\hline \multirow[t]{2}{*}{$\mathrm{Bt}$} & $55-65$ & 334 & 611 & 55 & 8 & 1.3 & 29 \\
\hline & $65-100$ & 334 & 610 & 56 & 7.4 & 0.9 & 28 \\
\hline \multicolumn{8}{|c|}{ Position 210} \\
\hline Ap & $10-20$ & 138 & 729 & 133 & 7.5 & 7.2 & 15 \\
\hline $\mathrm{E}$ & $30-40$ & 140 & 740 & 120 & 7.8 & 6.8 & 16 \\
\hline \multirow[t]{2}{*}{$\mathrm{E} \& \mathrm{Bt}$} & $40-50$ & 280 & 640 & 80 & 8.0 & 1.6 & 27 \\
\hline & $50-60$ & 303 & 634 & 63 & 8.0 & 1.3 & 27 \\
\hline \multirow[t]{2}{*}{$\mathrm{Bt}$} & $60-70$ & 328 & 612 & 60 & 8.1 & 1.2 & 29 \\
\hline & $70-100$ & 329 & 614 & 57 & 8.0 & 1.1 & 26 \\
\hline \multicolumn{8}{|c|}{ Position 60} \\
\hline Ap & $10-20$ & 133 & 737 & 130 & 7.6 & 7.6 & 16 \\
\hline $\mathrm{E}$ & $25-35$ & 135 & 741 & 124 & 7.8 & 7.9 & 15 \\
\hline \multirow[t]{2}{*}{$E \& B t$} & $35-45$ & 162 & 742 & 96 & 8.1 & 1.7 & 16 \\
\hline & $45-55$ & 169 & 745 & 86 & 8.0 & 1.2 & 15 \\
\hline \multirow[t]{2}{*}{$\mathrm{Bt}$} & $55-65$ & 263 & 666 & 71 & 8.0 & 1.2 & 25 \\
\hline & $65-100$ & 334 & 605 & 61 & 7.9 & 1.2 & 27 \\
\hline
\end{tabular}

n.d.: not determined. 
Table 2. / Relative abundance and properties of the different soil volumes as a function of the distance to the drain

\begin{tabular}{|c|c|c|c|c|c|c|}
\hline & $\begin{array}{l}\text { Distance to the drain } \\
\text { (cm) }\end{array}$ & $\begin{array}{l}\text { White- } \\
\text { grey }\end{array}$ & $\begin{array}{l}\text { Pale- } \\
\text { brown }\end{array}$ & $\begin{array}{l}\text { Salmon- } \\
\text { brown }\end{array}$ & Ochre & Black \\
\hline \multicolumn{7}{|c|}{ Relative abundance of the different soil volumes in $\%$} \\
\hline \multirow{3}{*}{$\begin{array}{l}\text { E\&Bt- } \\
\text { horizon }\end{array}$} & 400 & 5 & 42 & & 52 & 1 \\
\hline & 210 & 5 & 40 & & 50 & 5 \\
\hline & 60 & 11 & 55 & & 24 & 10 \\
\hline \multirow[t]{3}{*}{ Bt-horizon } & 400 & 1 & 11 & 14 & 73 & 1 \\
\hline & 210 & 1 & 12 & 10 & 74 & 1 \\
\hline & 60 & 4 & 30 & 10 & 52 & 4 \\
\hline \multicolumn{7}{|c|}{ Bulk density in $\mathrm{g} \mathrm{cm}^{-3}$} \\
\hline \multirow{3}{*}{$\begin{array}{l}\text { E\&Bt- } \\
\text { horizon }\end{array}$} & 400 & 1.68 & 1.68 & & 1.71 & 1.71 \\
\hline & 210 & 1.68 & 1.68 & & 1.71 & 1.71 \\
\hline & 60 & 1.68 & 1.68 & & 1.71 & 1.71 \\
\hline \multirow[t]{3}{*}{ Bt-horizon } & 400 & 1.70 & 1.70 & 1.75 & 1.75 & 1.75 \\
\hline & 210 & 1.70 & 1.70 & 1.75 & 1.75 & 1.75 \\
\hline & 60 & 1.70 & 1.70 & 1.75 & 1.75 & 1.75 \\
\hline \multicolumn{7}{|c|}{ Fe total concentrations in $\mathrm{g} 100 \mathrm{~g}^{-1}$} \\
\hline \multirow{3}{*}{$\begin{array}{l}\text { E\&Bt- } \\
\text { horizon }\end{array}$} & 400 & 1 & 1.5 & & 3.7 & 4.5 \\
\hline & 210 & 1 & 1.5 & & 3.8 & 4.5 \\
\hline & 60 & 0.8 & 1.2 & & 3.3 & 3.3 \\
\hline \multirow[t]{3}{*}{ Bt-horizon } & 400 & 1.4 & & 2 & 3.5 & 4.4 \\
\hline & 210 & 1.3 & & 1.8 & 3.1 & 3.8 \\
\hline & 60 & 1 & 1.4 & 2.2 & 4.1 & 4.2 \\
\hline
\end{tabular}




\begin{tabular}{|c|c|c|c|c|c|c|}
\hline & $\begin{array}{l}\text { Distance to the drain } \\
\text { (cm) }\end{array}$ & $\begin{array}{l}\text { White- } \\
\text { grey }\end{array}$ & $\begin{array}{l}\text { Pale- } \\
\text { brown }\end{array}$ & $\begin{array}{l}\text { Salmon- } \\
\text { brown }\end{array}$ & Ochre & Black \\
\hline \multirow{3}{*}{$\begin{array}{l}\text { E\&Bt- } \\
\text { horizon }\end{array}$} & 400 & 100 & 160 & & 240 & 5600 \\
\hline & 210 & 110 & 240 & & 300 & 4200 \\
\hline & 60 & 90 & 220 & & 260 & 4400 \\
\hline \multirow[t]{3}{*}{ Bt-horizon } & 400 & 90 & & 110 & 200 & 4500 \\
\hline & 210 & 90 & & 120 & 170 & 1200 \\
\hline & 60 & 90 & 140 & 130 & 180 & 5400 \\
\hline \multicolumn{7}{|c|}{ Lutum concentrations in $\mathrm{g} 100 \mathrm{~g}^{-1}$} \\
\hline \multirow{3}{*}{$\begin{array}{l}\text { E\&Bt- } \\
\text { horizon }\end{array}$} & 400 & 20 & 21 & & 30 & \\
\hline & 210 & 17 & 19 & & 32 & \\
\hline & 60 & 14 & 16 & & 17 & \\
\hline \multirow[t]{3}{*}{ Bt-horizon } & 400 & 29 & & 35 & 32 & \\
\hline & 210 & 24 & & 33 & 32 & \\
\hline & 60 & 18 & 19 & 33 & 33 & \\
\hline \multicolumn{7}{|c|}{ Quartz concentrations in $\mathrm{g} 100 \mathrm{~g}^{-1}$} \\
\hline \multirow{3}{*}{$\begin{array}{l}\text { E\&Bt- } \\
\text { horizon }\end{array}$} & 400 & 64 & 63 & & 52 & \\
\hline & 210 & 65 & 65 & & 49 & \\
\hline & 60 & 71 & 71 & & 63 & \\
\hline \multirow[t]{3}{*}{ Bt-horizon } & 400 & 54 & & 50 & 52 & \\
\hline & 210 & 53 & & 50 & 51 & \\
\hline & 60 & 66 & 64 & 50 & 48 & \\
\hline
\end{tabular}


Table 3. / Means \pm standard deviation of the $\mathrm{Mn} / \mathrm{Fe}$ ratio in the different soil volumes independently from the drain distance

\begin{tabular}{|l|l|l|l|}
\hline & & \multicolumn{2}{|l|}{ Mn/Fe ratio } \\
\cline { 3 - 4 } Horizon & Volume & Ferrihydrite & Goethite \\
\hline E\&Bt & White-grey & $55 \pm 23$ & $29 \pm 3$ \\
\hline & Pale-brown & $82 \pm 20$ & $27 \pm 3$ \\
\hline & Ochre & $82 \pm 26$ & $17 \pm 3$ \\
\hline & Black & $192 \pm 78$ & $25 \pm 6$ \\
\hline Bt & White-grey & $59 \pm 30$ & $25 \pm 3$ \\
\hline & Salmon-brown & $44 \pm 8$ & $36 \pm 19$ \\
\hline & Ochre & $52 \pm 9$ & $15 \pm 3$ \\
\hline & Black & $136 \pm 61$ & $21 \pm 2$ \\
\hline
\end{tabular}

Table 4. / Fe masses lost as ferrihydrite, goethite and smectites, and as lutum at position 60

\begin{tabular}{|l|c|l|}
\hline Mineral & Fe mass lost $\left(\mathrm{g} \mathrm{m}^{-\mathbf{2}}\right)$ as & Lost mass $\left(\mathbf{g ~ m}^{-\mathbf{2}}\right)$ \\
\hline Ferrihydrite: $\mathrm{Fe}_{5} \mathrm{HO}_{8} \cdot 4 \mathrm{H}_{2} \mathrm{O}^{\underline{a}}$ & 6400 & 11,000 \\
\hline Goethite: $\mathrm{FeOOH}^{\underline{\mathrm{a}}}$ & 5700 & 9100 \\
\hline Smectites: $\mathrm{Si}_{8} \mathrm{Al}_{3,2} \mathrm{Fe}_{0,2} \mathrm{Mg}_{0,6} \mathrm{O}_{20}(\mathrm{OH})_{4}{ }^{\underline{a}}$ & 1500 & 97,000 \\
\hline Total mass lost $\left(\mathrm{g} \mathrm{m}^{-2}\right)$ & & 117,100 \\
\hline Lutum mass lost $\left(\mathrm{g} \mathrm{m}^{-2}\right)$ & & $113,000^{\underline{b}}$ \\
\hline
\end{tabular}

${ }^{\mathrm{a}}$ The structural formulae of ferrihydrite and goethite are from Cornell and Schwertmann (1996), that of smectites from Sposito (1989).

${ }^{\mathrm{b}}$ Result published in (Montagne, 2006). 